\title{
What should be considered to get a lot of adipose derived stem cells?
}

\author{
Woo Jung Ho and Hea-Jo Yoon* \\ Stem Cell Research Center, Apgujeong Miracle Clinic, South Korea
}

\begin{abstract}
Adipose derived stem cells (ASCs) are derived from mesenchyme and have several general or unique characteristics. ASCs have more colony frequency, higher proliferation capacity and can be cultured longer compared with bone marrow-derived mesenchymal stem cells. The yield, frequency of ASCs, the number of viable cells, proliferation and differentiation potential, and growth characteristics of ASCs have various spectrum according to the methods of harvesting, adipose tissue site for harvesting, and patient's individual characteristics.
\end{abstract}

\section{Introduction}

Mesenchymal stem cells (MSCs) play an important role in cellular therapy. The bone marrow is the first source that has been found to have MSCs. Adipose tissue, like bone marrow, is the mesenchymal origin and contains a supportive structure that is easily digested and isolated.

There are several reports regarding comparisons of yield, colony frequency, sustainable duration of cell culture and proliferation between ASCs and BM-MSCs. The yield of ASCs is approximately 5000 CFU-F (colony forming units-fibroblast) per gram of adipose tissue, and this could be compared with 100-1000 CFU-F per millilitre of bone marrow [1]. The bone marrow has a capacity limit of $40 \mathrm{ml}$ under local anaesthesia, so $2.4 \times 10^{4}$ stem cells could be obtained from $40 \mathrm{ml}$ volume of human bone marrow. On the other hand, $1 \times 10^{6}$ ASCs can be harvested from $200 \mathrm{ml}$ of adipose tissue under local anaesthesia, so the difference is 40-fold [1]. Moreover, ASCs have a higher colony frequency, longer incubation and higher proliferation capacity than BM-MSCs [2].

ASCs are easier to obtain in large quantities than BM-MSCs and have favourable conditions for culture, but the colony frequency, proliferation and differentiation functions of ASCs differ depending on the harvesting methods, harvesting site, and individual characteristics.

\section{Variations according to the methods of harvesting adipose tissue}

Depending on the methods of extracting adipose tissue to obtain ASCs, the yield, number of viable cells and growth characteristics of ASCs may differ. Numerous different procedure and tools for harvesting ASCs-containing fat tissue have been established. Especially, viability of ASCs is one of the important tools to measure the stress applied to adipose tissue during harvesting [3]. Keck et al. have shown that suction- assisted liposuction resulted in yield and viability of ASCs comparable to manual liposuction [4]. Alternatively, laser-assisted liposuction has been demonstrated to decrease ASCs yield and viability as compared with suction-assisted liposuction [3]. OedayrajsinghVarma et al reported that the number of viable cells in the SVF was similar regardless of the harvesting procedure, but ASCs obtained by ultrasound-assisted liposuction had a lower frequency of proliferating, a longer population doubling time than ASCs obtained by resection [5]. Conversely, according to study of Duscher et al, ultrasoundassisted liposuction (pulsed ultrasound energy to selectively emulsify subcutaneous adipose tissue) and suction- assisted liposuction showed similar results in terms of yield, viability, and metabolic activity [3].

\section{Variations according to adipose tissue site for harvesting}

The anatomical location used for harvesting adipose tissue may also affect the yield, frequency and function of ASCs. The abdomen and hip/thigh area are the most frequently used anatomical sites for harvesting. Oedayrajsingh-Varma et al have found the yield of nucleated cells in the SVF from different tissue-harvesting sites was similar [5]. The frequency of ASCs (determined by limiting dilution and CFU-F) was higher in SVF derived from abdominal fat than in SVF isolated from hip / thigh area [6]. However, differentiating potential, the growth kinetics and surface marker expression of ASCs from both tissue-harvesting sites are similar [6]. ASCs from the same site exhibit differences in cell yield depending on the harvest depth [7].

\section{Characterization of ASCs according to patient's individual variation}

The characteristics of ASC may change depending on the age, gender, BMI, and diseases such as diabetes and osteoarthritis of the person from whom subcutaneous fat was obtained [8]. Hauner et al reported no relationship between BMI or age and numbers of ASCs per gram of adipose tissue [9]. However, there are reports that the individual characteristics of patients affect proliferation and differentiation of

${ }^{*}$ Correspondence to: Hea-Jo Yoon, Stem cell research centre, Apgujeong miracle clinic, Seoul, South Korea, Tel: 8215887013, Fax: 8220007822, E-mail: heajo7890@daum.net

Key words: adipose derived stem cells, characteristics, yield, harvesting

Received: January 18, 2019; Accepted: March 01, 2019; Published: March 04, 2019 
ASCs. Yang et al demonstrated that increased age led to decreased cell yield cell, growth ASCs proliferation and adipogenic differentiation [8]. They also found that BMI did not affect the cell yield or growth rate but did affect differentiation [8]. The inconsistency of the effects of individual characteristics on the yield, proliferation, and differentiation of ASCs may be due to confounding factors such as varied fat extraction methods, processing methods, and culture conditions.

\section{References}

1. Strem BM, Hicok KC, Zhu M, Wulur I, Alfonso Z, et al. (2005) Multipotentia differentiation of adipose tissue-derived stem cells. Keio J Med 54: 132-141. [Crossref]

2. Kern S, Eichler H, Stoeve J, Klüter H, Bieback K (2006) Comparative analysis of mesenchymal stem cells from bone marrow, umbilical cord blood, or adipose tissue. Stem Cells 24: 1294-1301. [Crossref]

3. Duscher D, Atashroo D, Maan ZN, Luan A, Brett EA, et al. (2016) Ultrasound-assisted liposuction does not compromise the regenerative potential of adipose-derived stem cells. Stem Cells Transl Med 5: 248-257. [Crossref]
4. Keck M, Kober J, Riedl O, Kitzinger HB, Wolf S, et al. (2014) Power assisted liposuction to obtain adipose-derived stem cells: impact on viability and differentiation to adipocytes in comparison to manual aspiration. J Plast Reconstr Aesthet Surg 67: e1-8.

5. Oedayrajsingh-Varma M, Van Ham S, Knippenberg M, Helder M, Klein-Nulend J, et al (2006) Adipose tissue-derived mesenchymal stem cell yield and growth characteristics are affected by the tissue-harvesting procedure. Cytotherapy 8: 166-177. [Crossref]

6. Jurgens WJ, Oedayrajsingh-Varma MJ, Helder MN, Zandiehdoulabi B, Schouten TE, et al. (2008) Effect of tissue-harvesting site on yield of stem cells derived from adipose tissue: implications for cell-based therapies. Cell Tissue Res 332: 415-426.

7. Fraser J, Wulur I, Alfonso Z, Zhu M, Wheeler E (2007) Differences in stem and progenitor cell yield in different subcutaneous adipose tissue depots. Cytotherapy 9: 459-467.

8. Yang HJ, Kim K-J, Kim MK, Lee SJ, Ryu YH, et al. (2014) The stem cell potential and multipotency of human adipose tissue-derived stem cells vary by cell donor and are different from those of other types of stem cells. Cells Tissues Organs 199: 373-383.

9. Hauner H, Entenmann G (1991) Regional variation of adipose differentiation in cultured stromal-vascular cells from the abdominal and femoral adipose tissue of obese women. Int J Obes 15: 121-126.

Copyright: $@ 2019$ Ho WJ. This is an open-access article distributed under the terms of the Creative Commons Attribution License, which permits unrestricted use, distribution, and reproduction in any medium, provided the original author and source are credited. 